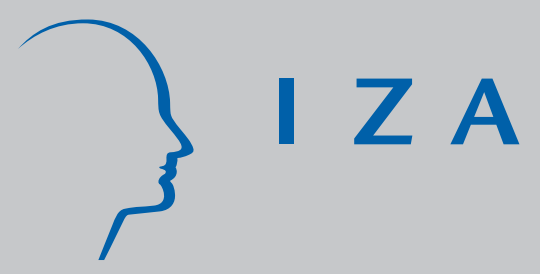

IZA DP No. 2778

Adult Outcomes for Children of Teenage Mothers

Marco Francesconi

May 2007 


\title{
Adult Outcomes for Children of Teenage Mothers
}

\author{
Marco Francesconi \\ University of Essex and IZA
}

Discussion Paper No. 2778

May 2007

IZA

P.O. Box 7240

53072 Bonn

Germany

Phone: +49-228-3894-0

Fax: +49-228-3894-180

E-mail: iza@iza.org

\begin{abstract}
Any opinions expressed here are those of the author(s) and not those of the institute. Research disseminated by IZA may include views on policy, but the institute itself takes no institutional policy positions.

The Institute for the Study of Labor (IZA) in Bonn is a local and virtual international research center and a place of communication between science, politics and business. IZA is an independent nonprofit company supported by Deutsche Post World Net. The center is associated with the University of Bonn and offers a stimulating research environment through its research networks, research support, and visitors and doctoral programs. IZA engages in (i) original and internationally competitive research in all fields of labor economics, (ii) development of policy concepts, and (iii) dissemination of research results and concepts to the interested public.
\end{abstract}

IZA Discussion Papers often represent preliminary work and are circulated to encourage discussion. Citation of such a paper should account for its provisional character. A revised version may be available directly from the author. 


\section{ABSTRACT}

\section{Adult Outcomes for Children of Teenage Mothers}

Using data from the British Household Panel Survey, this study examines the relationship between several outcomes in early adulthood (e.g., education, inactivity, earnings, and health) and being born to a teenage mother. Besides standard cross-sectional multivariate regression estimates, we also present evidence from nonparametric estimates and from estimates that account for unmeasured family background heterogeneity by comparing siblings born to the same mother who timed their births at different ages. Regardless of the econometric technique, being born to a teenage mother is usually associated with worse outcomes. An important channel of transmission of this adverse effect is childhood family structure, which plays a more powerful role than childhood family poverty. Albeit smaller, some of the detrimental effects are also found for children of mothers who gave birth in their early twenties.

JEL Classification: $\quad$ C23, I31, J13

Keywords: teenage pregnancy, intergenerational processes, endowment heterogeneity, identification issues, sibling estimators

Corresponding author:

Marco Francesconi

Department of Economics

University of Essex

Colchester CO4 3SQ

United Kingdom

E-mail: mfranc@essex.ac.uk

\footnotetext{
" I would like to thank Richard Berthoud, John Ermisch, Bertil Holmlund, Chuck Manski, Wilbert van der Klaauw, and Ken Wolpin for valuable comments and suggestions. The financial support from the UK Department of Health ("Long-term Consequences of Teenage Births for Parents and their Children", award number 037/0011) is gratefully acknowledged. The views expressed herein are those of the author and not necessarily those of the Department of Health.
} 


\section{Introduction}

In the United Kingdom, one in 30 women aged less than 20 had a child in 1998. This means that about 13 percent of twenty-year old women were expected to have a child in their teens (UNICEF, 2001). These rates, which were (and still are) three times as high as the European average, place the UK at the top of the teenage fertility table in Europe, and, among rich nations worldwide, second only to the United States where 22 percent of twenty-year old women are expected to become mothers in their teens.

What are the long-term consequences of teenage childbearing for parents and their children? In the case of parents, there is a large body of research. There is however a remarkable lack of consensus about the causal links between early parenting and parents' subsequent outcomes (for a review of the literature, see Coley and Chase-Lansdale, 1998). Although part of the different results can be related to differences in data sources and sample inclusion criteria and to the choice of conditioning variables, the main issue of debate in this literature is the way in which unobserved family background factors are accounted for in estimation. In the case of children's outcomes, in particular when children are adolescents or young adults, the body of research is more limited. Yet the perspective of children should be central to public policy design, especially in view of the many attempts at reducing child poverty. This paper contributes precisely to our understanding of these intergenerational issues, by addressing the question of whether a number of outcomes in early adulthood are associated with experience being born to a teenage mother.

The relationships between teenage childbearing and young people's outcomes are complex. These may not be the result of teenage motherhood per se, but they may simply reflect the characteristics of families in which children of teenage mothers are brought up. To complicate matters, some of those family characteristics may not be fully observed (e.g., parents' aspirations and fecundity, work ethics, and family commitment). In addition it is hard to disentangle whether the associations that we measure are a consequence of the timing of 
childbearing or the consequences of associated disadvantages. Therefore the causal effects of teenage childbearing on young people's outcomes cannot be easily identified (Rosenzweig and Wolpin, 1995).

To address this critical issue of identification, the analysis is performed using a number of estimators which place different assumptions on the data. We contrast results obtained from sibling differences — which account for observed and unobserved characteristics that are shared within the family of origin — to results obtained from more conventional level estimators which require stronger assumptions than sibling-difference estimators - to results obtained from simple mean comparisons. For earlier analyses of kinship data with different applications, see Chamberlain and Griliches (1977), Rosenzweig and Wolpin (1980 and 1995), Rosenzweig (1986), Strauss (1990), Geronimous and Korenman (1993), Currie and Cole (1993), Ashenfelter and Krueger (1994), Ermisch and Francesconi (2001a and 2001b), and Holmlund (2005).

We find that mean comparisons, level estimates and sibling-difference estimates point to similar conclusions. Being born to a teenage mother is usually associated with worse outcomes as young adults: lower chances of higher educational attainment, greater risks of inactivity and teenage childbearing, smaller probability of being in the top decile of the income distribution and greater probability of being in the bottom decile of the earnings distribution. We also find that children of teen mothers have worse outcomes if they grew up in a non-intact family, but not so much so if they grew up in a low-income family. Finally, albeit smaller, some negative effects also emerge among children of mothers who gave birth in their early twenties, suggesting that public policies targeting only teenage parenthood may not be enough to address social exclusion and disadvantages of all young parents and their families.

The paper unfolds as follows. In the next section we review several previous studies that provide the background against which our research should be contrasted. Section 2 presents the data, and describes the outcomes, the main independent variable and the other conditioning variables used in estimation. Section 3 outlines the statistical methods employed in the analysis, 
while Section 4 reports our results. This section explores two channels through which the adverse effect of having a teen mother could operate, namely childhood family poverty and childhood family structure, and looks for discontinuities in the effect of mother's age at birth. Section 5 summarises our main conclusions.

\section{Related Literature}

Teen motherhood is commonly believed to cause long-term socioeconomic and public health disadvantages, such as lower birth weights, education, work experience and wages, more persistent poverty and welfare dependency, and higher rates of infant mortality, substance abuse and violent crime (Furstenberg et al., 1987; Hofferth, 1987; Jenks, 1989; Hoffman et al., 1993; Kiernan, 1997). Recent strands of the sociological and economic literatures have argued that the adverse effects of teenage childbearing primarily reflect unmeasured family background rather than the true consequences of a teen birth (Geronimus and Korenman, 1992; Ribar, 1994; Hotz et al., 1997; Hotz et al., 2002; Levine et al., 2001; Brien et al., 2002; Ermisch and Pevalin, 2003). Despite these arguments, several analyses have confirmed that accounting for unobserved family background reduces, but does not eliminate, the estimated consequences of early childbearing (e.g., Bronars and Grogger, 1994; Klepinger et al., 1999; Chevalier and Viitanen, 2003; Goodman et al. 2004). So the reduction of teenage parenthood is still seen as an effective strategy for improving the life chances of very young parents or, at the very least, not compounding the handicaps imposed by the disadvantage associated with it.

Although it has long been recognised that teenage childbearing is likely to carry substantial costs to children, most of the available research has focused on mothers. By comparison, we know less on the intergenerational effects of teenage motherhood. One exception is the frequently cited pattern of repetitions of early births across generations: daughters of teen mothers are found to face significantly higher risks of teen pregnancy than daughters of older mothers (Presser, 1978; Card, 1981; Kahn and Anderson, 1992; An et al., 
1993; Kiernan, 1997; Manlove, 1997; Haveman et al., 1997). But, as in the case of the literature on mothers, we generally do not know whether or not unmeasured family background heterogeneity overstates the consequences of teen fertility. In addition, we have more limited knowledge about other behavioural outcomes for children of teen mothers, such as their educational achievements, labour market involvement, and mental health (Graham et al., 1994; Haveman and Wolfe, 1995). Yet a better understanding of the intergenerational links between mother's teenage fertility and later child outcomes and establishing whether such links are causal are central to public policy concerns because they shed light on the potential transmission of poverty and disadvantage across generations.

There are however a few important contributions along this vein of analysis. Geronimus and Korenman (1993) and Geronimus et al. (1994) account for unobserved background factors by using fixed-effects cousin comparisons. They respectively find no negative effects (and a few positive effects) on most of their infant health outcomes, and no effects on children's cognitive development or home environments. Comparing the children born to women when they were teens with children born later to women who began childbearing as adolescents, Grogger (1997) finds significant adverse effects of mother's teenage childbearing on male incarceration rates. Using explicit family background controls (but without the support of specific instruments or quasi-natural experiments), Haveman et al. (1997) and Hardy et al. (1997) find evidence of lower educational attainment, higher risks of early fertility and worse economic outcomes. Again with explicit control variables to account for the effect of maternal background, Levine et al. (2001) find that children of teen mothers are more likely to initiate early sexual activity and to display problem behaviour such as truancy and fighting. But teenage childbearing seems to play little or no causal role for academic outcomes, such as cognitive test scores and grade repetition. So, these studies provides us with mixed evidence on the effects of mother's teenage childbearing on child outcomes, some studies finding adverse and significant effects on children’s wellbeing, others finding either no significant effect or a positive impact. 
The lack of adequate data has limited research for Britain, where most of the available evidence is on the effect of teenage childbearing on mothers (e.g., Joshi et al., 1996; Kiernan, 1997; Chevalier and Viitanen, 2003; Ermisch and Pevalin, 2003; Goodman et al., 2004). Two exceptions are the analyses by Kiernan and Diamond (1983) and by Manlove (1997). Using longitudinal data from the 1946 National Survey of Health and Development (NSHD), the former study finds that children of parents who marry at an early age (used as a proxy for early parenthood) are likely to become parents relatively early themselves, net of educational and occupational statuses. Manlove instead uses longitudinal data from the 1958 National Child Development Study (NCDS) and finds that, even after controlling for a large set of family, school, and individual factors, daughters of teen mothers are more likely to have a birth in their teens and into their early twenties.

The present paper uses new data to examine a variety of young people's outcomes and to create a more complete picture of the relationship between maternal age at birth and child outcomes. It contributes to the relevant literature in three important ways. First, it focuses not only on teenage childbearing but also on other young adult outcomes, and as diverse as educational achievement, inactivity, wages and smoking. Second, we use data from the British Household Panel Survey, which have never been analysed before for this purpose. Although there might be instances of small cell sizes, these data have some clear advantages over the NSHD and the NCDS data. For example, they are a better reflection of contemporary impacts of family background, which may be particularly important for that of early births (because the incidence of teenage childbearing and the type of teenage parents are likely to be different now from those observed among the 1946 and 1958 birth cohort members). ${ }^{1}$ Third, because our data contain information on siblings, they allow us to control for unobserved additive effects that are

\footnotetext{
${ }^{1}$ Moreover, our data allow for better (albeit not ideal) measurement of family economic circumstances. On the other hand, the NSHD and the NCDS have more measures of non-economic background factors.
} 
shared by children who belong to the same family. ${ }^{2}$ To our knowledge, ours is the first paper for Britain that pays explicit attention to unobserved family background factors that might account for teenage motherhood's apparently detrimental effects.

\section{The Data}

The data come from a special sample of young adults selected from the first nine waves of the British Household Panel Survey (BHPS), covering the period between 1991 and 1999. In Autumn 1991, the BHPS interviewed a representative sample of 5,500 households, containing about 10,000 people. $^{3}$

\subsection{Sampling Strategy and Estimating Samples}

To estimate the long-term effects of teenage childbearing on children's outcomes as young adults, we first matched young adults (aged 16 or above) in the study to one or both of their biological or adoptive parents interviewed in at least one of the nine available waves. ${ }^{4}$ We then used the information that parents had provided about their fertility histories to determine whether a young adult was born to a mother when she was aged less then 20 . We also used the information about parents' family and work histories to determine the patterns of family structure and parental worklessness that applied when their children were growing up, that is, from birth to age 16. By construction, therefore, all the parental variables (including mother's age at birth) are obtained directly from the parents, while the child variables (both outcomes and characteristics) are obtained from the adult children as they followed in the panel.

\footnotetext{
${ }^{2}$ By collecting information on individuals born in one week of March 1946 or March 1958, the NSHD and NCDS, respectively, are instead not suitable for an estimation procedure based on sibling differences.

${ }^{3}$ Individuals from the Scottish and Welsh booster samples (who were first interviewed in 1999) are not included in this analysis. More information on the BHPS is available at $\langle$ http://www.iser.essex.ac.uk/ulsc/bhps/>.

${ }^{4}$ We have a lower bound at age 16 because the minimum age at which the BHPS starts collecting individual information is 16. The adolescent module of the BHPS has followed all children aged 11-15 since 1994 and contains information on their aspirations and expectations. The analysis of such outcomes is left for future research.
} 
This sampling strategy yielded a sample of 948 men and 839 women (a total of 1,787 individuals) who: (a) were aged 16 or over and were born between 1970 and 1983; (b) did not have any serious health problems or disabilities; (c) were living with their biological, adoptive or step-parent(s) for at least one year during the first nine waves of the panel study (1991-1999); and (d) had mothers from whom complete employment histories had been gathered covering their entire childhood (from birth to their $16^{\text {th }}$ birthday) as well as information on other background variables (see subsection 2.3).

We imposed condition (a) in order to have a relatively homogeneous group of young adults, who went through a similar educational system, yet allowing for a sufficiently large number of birth cohorts. Condition (b) was introduced to reduce the problem of parents' choosing their family and employment patterns during the child's childhood based on health considerations for the child. ${ }^{5}$ Condition (c) was imposed so that data on family background from the parents' records could be reliably matched with data on their child. Indeed, this is the only way in which we can obtain information on whether or not each young adults was born when his/her mother was aged less than $20 .{ }^{6}$ Finally, condition (d) was used so that, by construction, we would have full information on variables that are presumably crucial in our analysis, such as parents' education and parental worklessness during childhood, a proxy for family poverty. Table 1a summarises the number of individuals present in the sample by gender and gives also the total number of person-wave observations.

Of the 1,789 individuals in the main sample, 604 (or 34 percent) could not be matched to their adult siblings in any of the panel years, either because their siblings were not interviewed between 1991 and 1999 (27 percent) or because they are only children (7 percent). The

\footnotetext{
${ }^{5}$ Including the 18 children with disabilities in the analysis does not alter our main results.

${ }^{6}$ This condition can lead to sample selection bias if the unobserved factors affecting young adults' outcomes also affect the probability that children coreside with their parents. For that reason we constructed a restricted sample, consisting of individuals who were living with at least one parent when aged 16-17. Over the 1990 s, 95 percent of all young people aged 16-17 lived at home with their parents. The estimates from this new sample were very similar to those found for the main sample and are thus not shown.
} 
distributions of the remaining 1,183 individuals are given in Table $1 \mathrm{~b}$. The 1,183 young adults in the sample who have been matched to at least one sibling come from 524 households: 408 of these households have 2 siblings in the sample, 98 have 3 siblings, 17 have 4 siblings, and 1 has 5 siblings. A total of 814 comparisons are then obtained from this sample.

\subsection{Child Outcomes}

Descriptive statistics of the outcome variables are in Table 2. In addition, to document the extent of observed heterogeneity between children of teen mothers and other children, Table A1 presents the means of the same variables distinguishing between young adults whose mother never had a child as a teenager and young adults whose mother had a child as a teenager. The subsample of young adults whose mothers had a child before their $20^{\text {th }}$ birthday is further broken down into the group of children born to a teen mother and their siblings born when their mother was older. By allowing us to see whether there are differences within families with a teenage mother, this second distinction will be relevant in interpreting some of our later results.

Education. The measure for educational attainment is whether young people achieved an Alevel pass or higher qualification. ${ }^{7}$ This is applied by taking the highest qualification that young people achieve in the last year in which they are interviewed. In addition, as it is rare to obtain A-levels before the age of 18, we limit the estimating sample for this outcome to people who are that age or older. On that basis, Table 2 shows that 62 percent of young adults have acquired at least one A-level. The between-family difference in education is huge (about 14 percentage points; first two columns in Table A1) and this is mainly driven by children of teen mothers who were born when their mother was aged less than 20 (first and last columns in Table A1).

\footnotetext{
${ }^{7}$ For non-British readers, “A(Advanced)-level” corresponds to education beyond high school, but short of a university degree, and attainment of three A-levels is typically a pre-requisite for university enrolment. We also performed our analysis on a more restrictive definition of educational attainment, that is, whether a young person achieved qualifications above A-level. The results obtained from this definition were very similar to those discussed below and are therefore not reported.
} 
Economic Inactivity. This outcome is defined as young people being unemployed and not being in full-time education, looking after children, or taking part in a government training programme. All the available person-wave observations are used to examine this outcome, which, on average, is around seven percent in any one year. Again, the between-family difference is large and accounted for by the large gap between children whose mother never had a child as a teenager and children born to women before their $20^{\text {th }}$ birthday.

Teenage Childbearing. This outcome is defined as young women having given birth before their twentieth birthday. Therefore, a woman stops contributing to the sample as soon as she has a child or if she is childless when she turns 20. A decision was taken to focus on women only, because relatively few men in the sample had become fathers by age 20 and lived with their children. Table 2 shows that, on average, two percent of previously childless women aged 16-20 have a child each year. As would be expected, the rate at which young women gave birth for the first time is highest for those aged 19 and lowest for 16-year-olds. As for the previous outcomes, the between-family differences are sizeable, but the differences within households with teen mothers are relatively small (third and fourth columns in Table A1).

Smoking and Psychological Distress. Our measure of smoking behaviour takes value of one if an individual regularly smokes at least one cigarette a day, and zero otherwise. We performed the empirical analysis using also another measure, based on whether or not an individual smokes 10 or more cigarettes a day, and obtained the same results as those presented below. In what follows, therefore, we use the simple measure of smoking and report the estimates for this outcome only. More than two in five young people smoke (Table 2), with children of teenage mothers being only moderately more likely to smoke than other children (first two columns of Table A1). The measure of mental health is based on the General Health Questionnaire (GHQ, 12 point measure). ${ }^{8}$ Young people are defined as experiencing a high level of psychological

\footnotetext{
${ }^{8}$ This measure is based on the following indicators: loss of concentration; loss of sleep; playing a useful role; ability to make decisions; feeling constantly under strain; problems overcoming difficulties; enjoyment of day-to-
} 
distress if their score in the GHQ-12 is greater than or equal to four (Goldberg et al., 1998). Nearly one in five young people report psychological distress. Table A1 indicates small between-family differences in distress, while the within-family difference is negligible.

Earnings and Wages. We use two pieces of information to gauge the financial success of young people in the labour market. The first is given by their monthly real labour income deflated by the 1999 Retail Price Index. The second is their hourly pay in constant (1999) prices. Over the 1991-1999 period, average earnings are about $£ 610$ per month, and the average hourly pay is nearly £4.50. After partitioning the distribution of monthly earnings by decile, the value at the $10^{\text {th }}$ percentile is about $£ 100$, while the value at the $90^{\text {th }}$ percentile is about $£ 1,200$. Partitioning the distribution of hourly pay gives a value of $£ 1.80$ at the $10^{\text {th }}$ percentile, and a value of $£ 7.50$ at the $90^{\text {th }}$ percentile. We analyse monthly earnings and hourly wages both at the bottom and at the top deciles, so that we have a total of four indicators of monetary performance in the labour market. Unsurprisingly, 10 percent of all young adults in the sample are in the bottom decile of the monthly earnings distribution, and another 10 percent are in the top decile. Similar figures emerge in the case of hourly wages. ${ }^{9}$

Total Individual Income. Total annual individual income is the sum of total annual labour income and total annual non-labour income, which in turn includes income support, unemployment benefits, pensions and allowances of various sorts, capital income and transfer income of all types. ${ }^{10}$ The average real (1999 prices) total annual income is just below £5,600. The value at the $10^{\text {th }}$ percentile of the income distribution is slightly over $£ 200$, while the value at the $90^{\text {th }}$ percentile is almost $£ 12,500$. We analyse two indicators, which complement the information given by earnings and wages. The first takes value one if an individual has a total

day activities; ability to face problems; unhappiness or feeling depressed; loss of confidence; belief in self-worth; and general happiness.

${ }^{9}$ Table A1 indicates a rather large variation across families and, at the same time, a small difference within households with teen mothers. The same emerges in the case of income.

${ }^{10}$ We prefer this individual measure over total family income, since the latter largely reflects current parental wealth for children who still live at home or marital decisions for people observed living with a partner. 
annual income that falls below the tenth percentile, and zero otherwise. This is the bottom decile of the total income distribution, which can be seen as a proxy measure for (individual) poverty. ${ }^{11}$ The second indicator takes value one if the total annual income of an individual is greater than or equal to the value at the ninetieth percentile. This defines the top decile, and can be interpreted as an indication of financial success.

\subsection{Focal Variable and Other Conditioning Variables}

Being Born to a Teenage Mother. The focal variable of our analysis, which takes the perspective of children, is the age of the mother at the child's birth, and not mother's age at first birth (as in most of the existing literature), because for this latter variable there are no within-family differences. Clearly the effect of mother's age at birth is related to birth order effects and appropriate controls have to be included to disentangle these two different effects (see below). Mother's age at birth ranges between 13.4 and 56.2, peaks at around 25, and its distribution is skewed to the right. ${ }^{12}$ Table 3 shows that mothers' average age at birth is 26.5 , which is only slightly greater than the median (26.2). Ninety percent of the young adults have mothers who were aged between 19.3 ( $5^{\text {th }}$ percentile) and 34.8 (95 ${ }^{\text {th }}$ percentile) at their birth. The main (independent) variable of interest in our empirical analysis is "being born to a teenage mother": this is equal to one if a young adult has a mother who was aged less than 20 at his/her birth, and zero otherwise. This is the case for 7.2 percent of the young adults in the sample. Another onethird have mothers who were aged 24-27 at the time of their birth, while another 13 percent had been born to mothers who were over 31 years of age at their birth. Of the 814 sibling comparisons available in the sample, 147 (or about 18 percent) have the required variation across mother's age for identification of the teenage mother effect. These refer to 112

\footnotetext{
${ }^{11}$ Clearly, an individual at the bottom decile of the individual income distribution may not be poor if he/she lives at home with non-poor parents or is married to (or cohabits with) a partner with sufficiently high income.

12 There is only one individual whose mother was aged 56.2 at the time of his birth. Dropping this case from the analysis does not change our subsequent findings. In fact, only 9 individuals (less than 0.5 percent of the whole sample) were born when their mothers were aged 40 or more, and none of such individuals shared the same mother with another individual in the sample. Dropping these cases from the analysis does not change our results.
} 
households. Of course, the identification of the same effect also requires within-family variation across outcomes, the extent of which can be gauged from Table A1.

Other Variables. Several conditioning variables are included in the analysis. Their inclusion is motivated by theory (Haveman and Wolfe, 1995) and by the effort to limit the extent to which having a teenage mother is correlated to other factors (see the discussion in Section 3). The set of covariates used here compares well with other previous studies (Card, 1981; Kahn and Anderson, 1992; Geronimus and Korenman, 1992; Grogger, 1997; Chevalier and Viitanen,). The summary statistics of such variables are in Table A2. These are computed on the whole sample using only one observation per individual for the last available year (for a total of 1,787 young adults). As in the case of the outcome variables, Table A3 presents the summary statistics for the same covariates both between and within families.

Just under half of the people in the sample were women. The age of the young adults ranged between 16 and 29, with an average just above 22, and the average year of birth being 1976. Individuals are evenly spread across age groups. The differences between families along those two characteristics are small, but, as documented in Table A3, children of teenage mothers tend to grow up in households with fewer female siblings.

By matching young adults with their mothers, we can measure other background characteristics (e.g., parents' education and family size) that would be otherwise unavailable in the BHPS. If fathers are successfully matched to their natural, adoptive or step-children then we also use that background information. If they are not matched or we could not obtain the information of interest, we retained children in the analysis to maximise on sample size and assign (arbitrary) values to the missing father's information. ${ }^{13}$ We performed several sensitivity tests and found that our results were robust to alternative assignments as well as to the exclusion

\footnotetext{
${ }^{13}$ In the econometric analysis, fathers with missing information on education have been assigned to the "no qualification" group, those with missing information on age at birth have been assigned to the 25-30 age group, those with missing work history information have been defined as "working", and those with missing smoking information have been assigned to the non-smoking group.
} 
of individuals with missing father's information (see Ermisch et al., 2001 and 2004). Table A1 shows that approximately 17 percent of the young adults in the sample did not have information about their father's working histories. An additional 13 percent did not have a 'father-figure' (i.e., biological or adoptive father or stepfather) present during the nine panel years who could be interviewed.

About 30 percent of mothers and just less than one-quarter of the fathers (with nonmissing information) in the sample had no academic qualifications, while nearly 45 percent of mothers and more than 50 percent of fathers have at least A-level or equivalent qualifications. ${ }^{14}$ Differences in terms of mother's education between families with and without a teenage mother are huge: children of teenage mothers have a substantially less educated mother as opposed to other children.

Approximately one in four young people had experienced life in a non-intact family during their first sixteen years of life. The family structure measure is also broken down by the timing of the start of a spell in a lone-parent family, distinguishing between three stages of childhood, ages $0-5,6-10$, and $11-15$ years. ${ }^{15}$ Of the individuals who lived in a non-intact family, some 43 percent had done so when they were aged $0-5$, another one-third had lived in a non-intact family when aged 6-10, and the remaining quarter experienced life in such a type of family during adolescence. The differences between different types of families are large (first two columns of Table A3): compared to children whose mothers did not have a teenage birth, those children whose mother did are two times more likely to have lived in a non-intact family. This could be an important pathway through which the effect of teenage fertility might work. We shall explore such a possibility in Section 4. In addition, the last two columns of Table A3

\footnotetext{
${ }^{14}$ In this paper we are not concerned with a causal interpretation of parents' education. For a recent analysis of this issue, see Black et al. (2005) and references therein.

${ }^{15}$ A description of how this variable has been constructed is in Ermisch and Francesconi (2001b). We have also experimented with measures that account for the proportion of childhood years lived in a non-intact family and found the same substantive results discussed later. For convenience, therefore, we do not present the results based on such exposure measures.
} 
show an interesting difference within families with a teenage mother: children of teenage mothers who were born when their mother was aged 20 or above are significantly less likely to have experienced life in a non-intact family as opposed to their (older) siblings.

Parental joblessness is a reliable indicator of dependence on social security benefits especially among families with children (Iacovou and Berthoud, 2000), and — when measured over the first sixteen years of life of a child — it can be seen as a proxy measure for childhood family poverty and household employment insecurity, which are not directly observed in the sample examined here (Ermisch et al., 2001). Table A1 reports the proportion of young adults whose parents had been observed workless sometime during their entire childhood and by child's age group. ${ }^{16}$ Differently from the family structure measure, having lived with workless parents when aged, say, 0-5 does not imply having lived with workless parents in the other age groups, nor does it exclude such a possibility. This is why the three figures by age group in Table A1 do not add up to the figure for all ages. Almost 47 percent of the young people in the sample have lived at least one year during their childhood in which both parents had some time off work. Interestingly, the largest incidence of parental joblessness (about 39 percent) is observed when the child was aged 0-5, the lowest (slightly less than 18 percent) when the child was an adolescent. Between-family differences are large, with children in teen-mother households being more likely to live with workless parents than other children; and withinfamily differences are also large, with children of teenage mothers experiencing the greatest exposure to parental joblessness.

As mentioned earlier, since the effect of mother's age at birth may be correlated with birth order effects, we also include an indicator variable that equals one if the respondent is the first-born in the family and another indicator variable that equals one if the respondent is an only

\footnotetext{
16 This variable has been constructed using the retrospective job history information collected in the third wave (1993) of the BHPS. Its construction is detailed in Ermisch et al. (2004). We also performed the whole analysis using variables based on the proportion of childhood years lived with workless parents. Since none of the estimates in Section 4 changed, we decided not to present the results obtained with such alternative variables.
} 
child. ${ }^{17}$ In addition, we take account of the number of brothers and number of sisters that each young adult has. About 7 percent of the young people in the sample are only children, and 36-37 percent are firstborn. Most of the young adults have one or two siblings, and on average they have 1.7 brothers and sisters (and a maximum of seven). On average, children living with a teenage mother live also in larger households than children in other households and are less likely to be only children (see the first two columns of Table A3).

\section{Econometric Issues and Methods}

A central concern of this study is that the estimated effect of being born to a teenage mother might be spurious. This is due to the mutual association that having a teenage mother and later child behaviour may share some unmeasured or unmeasurable factors. For example, there might be genetic factors and cultural characteristics (e.g., sexual attraction, fecundity, family environment, and peer pressure) that make a woman more likely to have a child in her teens. Such factors, which can be partly passed on across generations, may directly affect her child's life chances. In general, therefore, the association between being born to a teenage mother and later child outcomes may not necessarily be the result of teenage motherhood per se. Rather, differences in outcomes could simply reflect the (sometimes unobserved, other times unobservable) characteristics of families in which children of teenage mothers are brought up. This means that the effect of being born to a teenage mother cannot be straightforwardly identified in large-scale nonexperimental studies, such as the BHPS, unless some structure is imposed on the data.

Our econometric strategy therefore is to apply four different methods. For the sake of brevity, we cannot describe them in detail, but provide appropriate references to which the

\footnotetext{
${ }^{17}$ In the (level and fixed-effects) regression analyses, we have also experimented with the inclusion of a full set of birth order variables, but we found them of such minor significance that we decided to include only the first-born dummy variable. Moreover, the inclusion of other birth order variables when estimating sibling-difference models is problematic, because for almost 85 percent of the sibling differences there are only two siblings.
} 
interested reader should turn. First, we compute bounds around the true effect of having a teenage mother on each of the outcomes described in the previous section using the technique suggested by Manski (1989, 1990, and 1995). The advantage of the bounds is that they are determined without imposing any parametric restriction on the data. They are in fact the only estimates that can be delivered without forcing any specific structure on the relationship of interest. The disadvantage of the bounds is that they do not pick out one point estimate but an interval, which can be rather large (and thus uninformative about the actual impact of having a teenage mother) even after conditioning on a wide set of observable exogenous characteristics. ${ }^{18}$

Second, we calculate mean differences, which are simple nonparametric estimates based on the rather stringent condition that the 'treatment' (being born to a teenage mother) is randomly assigned (Manski et al., 1992). That is, conditional on observables, the realised outcomes are mean-independent of the treatment, regardless of whether the treatment occurs or not. Manski (1995) refers to these as nonparametric estimates or estimates based on the conditional independence assumption (see also Ermisch et al., 2004). ${ }^{19}$ This assumption is likely to be untenable if unobservable factors, which affect the mothers' likelihood of having a teenage birth, are systematically correlated to child outcomes. These estimates, however, are easy to compute and represent a useful benchmark for the next two sets of point estimates.

Third, we compute estimates from parametric models using standard multivariate regressions (e.g., Kiernan and Diamond, 1983; Manlove, 1997). The results of the analysis that treats each young adult as an individual observation in the sample are known as between-family (or level) estimates. In calculating them, we use all the variables listed in Table A1. Failure to apply these controls would risk confusing any effect of mother's age at birth with the association

\footnotetext{
${ }^{18}$ We estimate the bounds for 288 cells that are defined on the basis of child's age, sex and birth order, mother's and father's education, and mother's age at birth. See also the note to Table 4 for further details.

${ }^{19}$ The nonparametric estimates shown in Table 4 are weighted averages of the conditional mean differences between treatment and control groups for the same 288 cells used to construct the Manski bounds. The weights are the size of each cell in the sample.
} 
between maternal 'endowments' and those of her children. ${ }^{20}$ Between-family models, however, must rely on strong assumptions to guarantee identification of the parameter of interest, even if many background variables are included. The level estimates presented here are obtained from logit regressions. Similar results were obtained from probit regressions and linear probability models, but we chose not to present them for the sake of brevity.

Fourth, the BHPS data allow us to estimate sibling-difference models, which acknowledge the fact that siblings or half-siblings share many family-specific characteristics and environmental factors (e.g., biological or social parents, their parenting style, parents' social and cultural environments, housing and, to a large extent, neighbourhoods and schools). This estimation is meant to eliminate most of such common factors by relating differences in outcomes between siblings to differences in their experience of being born to a teenage mother as well as differences in other time-varying covariates, while all variables that are fixed over time and shared among siblings (e.g., mother's education) cannot be identified. Ermisch and Francesconi (2001b) and Ermisch et al. (2004) show that a sibling difference (or within-family) estimator generally identifies treatment effects under milder conditions than the between-family estimator does. The key sufficient condition for the sibling difference estimator to identify the effect of being born to a teenage mother is that mothers' fertility choices do not respond to the child's idiosyncratic endowments. Given that the child is not born yet at the time his/her mother gets pregnant, this may be seen as a relatively mild assumption. If, however, fertility choices are correlated to endowments that can be transmitted intergenerationally at least in part (e.g., attractiveness, fecundity, and sexual attitudes), this assumption becomes more problematic. ${ }^{21} \mathrm{~A}$ further problem with within-family estimators is that heterogeneity within the family, such as

\footnotetext{
${ }^{20}$ Our regressions are more parsimonious than those estimated by Manlove (1997) who includes controls for family and individual characteristics and home environment factors measured at birth or at age 7, 11 or 16. Similarly, Levine et al. (2001) control for a larger number of child's background characteristics and mother's ability. These measures are not available in the BHPS data.

${ }^{21}$ Beside this condition, consistency of the between-family estimator must also require that mother's fertility choices do not depend on family endowments, or that there is no degree of inheritability of unobserved factors. Both such additional assumptions are arguably strong.
} 
pre-motherhood characteristics (Holmlund, 2005), may still bias the estimates. In our context, however, this should not be a concern because our focus is on children rather than mothers.

We computed the within-family estimates in three different ways: using Chamberlain conditional logit models; using mother fixed-effects linear probability models; and using mother fixed-effects logit models. In this last type of regressions, the dependent variable takes value of 1 if one the siblings (sorted first) reaches the outcome of interest (e.g., has an A-level or higher qualification, smokes or is inactive) and the other sibling does not and 0 otherwise (Rosenzweig and Wolpin, 1995). If, in a sibling pair, the second sibling is the only one who, say, is inactive, then all the right-hand side variables are sorted accordingly. Because of this non-random sorting of siblings, a constant term must also be included in such regressions (see Ashenfelter and Rouse, 1998). Differently from the linear probability model, this method avoids the standard problem of predicting probabilities outside the unit interval. On the other hand, its advantage over the Chamberlain conditional logit model is that it uses all the available sibling comparisons rather than just those for which there is a difference in the dependent variable, and therefore increases estimate efficiency. Of course, the identifying cases are the same and, in fact, the point estimates from these two methods are the same, and the difference is in their standard errors. For convenience, therefore, we chose to present the results from these last regressions only. The overall results obtained from the other two types of regressions were very similar.

To ease the interpretation, all estimates will be presented in the same format: they give an assessment of the 'marginal effect' of being born to a teenage mother on young adults' outcomes after controls have been applied for other variables (calculated at their sample values). The reading of the Manski bounds and nonparametric estimates is again straightforwardly done in probability terms. For example, in Table 4, the baseline probability of attaining A-level or higher qualifications is 62.3 percent. The lower bound suggests that 20 percentage points ought to be subtracted from, while the upper bound suggests that 5 points must be added to the baseline to obtain the possible range of the effect of being born to a teenage mother. The effect 
therefore must lie between 42.3 percent $(=0.623-0.200)$ and 67.3 percent $(=0.623+0.050)$. The same calculations apply to the other outcomes. For the same outcome, the nonparametric estimate points to a negative marginal effect of 20.4 percentage points. Again, to gauge the full impact of being born to a teenage mother, this figure must be added to the baseline probability. Thus, on average, children of teen mothers will have a 41.9 percent probability of achieving Alevel of higher qualifications, just outside the Manski bounds. Similar computations apply to the level and sibling difference estimates and for all other outcomes. ${ }^{22}$

\section{Results}

\subsection{Benchmark Estimates}

Table 4 contains our main estimates. The treatment is having a teenage mother, and the control is having a nonteen mother. In the control group, mothers could be as young as 21 or as old as 57 at their child's birth. Most of the point estimates fall within the Manski bounds. ${ }^{23}$ This means that, in general, the assumptions needed to obtain the point estimates in Table 4 are probably not off the mark. It may also mean that the Manski bounds are not informative enough to restrict the range of possible effects to a tighter interval.

In what follows we focus on the estimates obtained from the sibling difference models, because they impose weaker assumptions for the identification of the effect of being born to a teenage mother as compared to the assumptions imposed by the nonparametric and betweenfamily estimators. Being born to a teenage mother is usually associated with negative outcomes for children as young adults. Children born to teen mothers have almost 13 percentage points lower probability of achieving A-level or higher qualifications than children of nonteen mothers.

\footnotetext{
${ }^{22}$ Throughout the analysis of the level and within-family models, we compute robust standard errors that are consistent even if the residuals are not identically and independently distributed., that is, the standard errors are robust to arbitrary forms of heteroskedasticity for individuals over time. In the case of the education outcome, when all variables are measured at the last available year for each individual, the standard error of the level estimates are robust to any form of correlation between siblings. For the Manski bounds and nonparametric estimates, instead, we compute bootstrap standard errors that are obtained with 500 replications.

${ }^{23}$ There are a few exceptions. In all such cases, however, the differences between the Manski bounds and the point estimates are never statistically significant at conventional levels.
} 
This differs from the evidence reported in Graham et al. (1994), which reveals no significant effect of mother's age at birth on years of schooling but it is based on between-family estimates.

Perhaps as a result of the reduced human capital accumulation, children of teenage mothers have also more limited economic prospects, at least at the beginning of their adult life. Compared to children of nonteen mothers, they are about 5 percentage points more likely to be economically inactive, they are nearly 3 percentage points less likely to be observed in the top decile of the distribution of personal income, and almost 4 percentage points more likely to be in the bottom decile of the monthly earnings distribution. Conversely, no effect is found in the case of hourly wages, perhaps reflecting the presence of noisy information for the intensive margin of young people’s labour supply. ${ }^{24}$

Interestingly, daughters of teen mothers are significantly more likely to be teenage mothers themselves: having a teenage mother in fact increases the chances of being a teenage mother by 2.7 percentage points, raising the overall probability from 2 percent at baseline to 4.7 percent, which represents a massive increase of 135 percent. This finding is important as it reveals a strong intergenerational link in teenage fertility behaviour, and confirms earlier results by Kiernan and Diamond (1983) and Manlove (1997) based on level estimates. Finally, the health outcomes under analysis (smoking and psychological distress) do not seem to be significantly affected by mother's fertility behaviour.

\subsection{Two Channels of Transmission during Childhood: Family Structure and Poverty}

The bulk of evidence presented so far suggests that being born to a teen mother has adverse consequences for children, as it tends to inhibit their socioeconomic mobility through lower education, earnings and income, and higher risks of inactivity and early childbearing. Since sibling difference estimates eliminate all unobserved family background factors that are fixed

\footnotetext{
${ }^{24}$ Income, wages and earnings regressions are not selectivity corrected. Selectivity-corrected regressions — which used exclusion restrictions on housing tenure, house prices and local unemployment rates — delivered virtually identical results (and are therefore not shown).
} 
over time and shared between siblings, there must be other channels through which such effects emerge. These must differ between siblings in the same family, otherwise they cannot contribute to the sibling differences by definition. The within-family differences in Tables A1 and A3 offer some clues. Two possible mechanisms emerging there are childhood poverty and family structure (see our discussion in Section 2.3). If teenage motherhood is associated with greater risks of family disruption and poverty than nonteen motherhood, then these other types of disadvantage would compound the risks of worse outcomes for children of teen mothers. Another example is siblings' individual ability. Presumably children with greater ability perform better in school and the labour market, unless parents compensate lower-endowment siblings with greater human capital investments (or greater inter vivos transfers). With our data however we cannot test this explanation. ${ }^{25}$

As a way of evaluating the role played by childhood family structure and poverty, we reestimate the within-family models for all outcomes after including two additional interaction terms. The first is between being born to a teenage mother (our treatment variable) and having ever lived with workless parents during childhood (our proxy measure for childhood poverty). The second interaction is between the treatment variable and having ever lived in a non-intact family during childhood. For the whole sample, only 4 percent of the person-wave observations are for people who were born to a teen mother and experienced life in a non-intact family by their sixteenth birthday, and another 6 percent of the observations are for people who were born to a teen mother and lived with workless parents sometime during childhood. We may have inferential problems if these small cell sizes lead to large estimated standard errors. Nonetheless the estimates from this exercise are policy relevant and likely to be informative. The results below are robust to the use of exposure (rather than incidence) measures of parental worklessness and family non-intactness. These alternative results are therefore not reported.

\footnotetext{
${ }^{25}$ We also assessed the role played by birth order effects, but found them to be of marginal significance. We therefore chose not to present the results from this analysis.
} 
The results are in Table 5 where we only report the estimates of the treatment and the two interaction terms. The direct effect of being born to a teen mother is substantial and statistically significant for the case of inactivity, teenage childbearing, income (top decile), and earnings (bottom decile). The only outcome for which it loses significance in relation to Table 4 is education. On this outcome, however, teenage motherhood has a negative effect if it is combined with family disruption during the first sixteen years of the child's life. The probability of achieving at least one A-level qualification for children of teen mothers who also lived in a non-intact family is about 7 percentage points lower than for children of teen mothers in intact families. The interaction term between teenage motherhood and having lived with jobless parents during childhood is instead not statistically significant. Similarly, for all the other significant effects of Table 4, most of the action in Table 5 seems to go through childhood family structure rather than childhood poverty. For instance, being born to a teen mother increases young adults' risk of inactivity by 3.7 percentage points on average, and if their mother broke up her partnership (or never partnered) their risk increases further by 2.8 points. The same risk increases also if young adults lived with jobless parents during childhood by 2 percentage points, but this increase is not statistically significant. The only outcome for which the interaction between poverty and teenage motherhood is statistically significant and large is psychological distress, with its effect increasing the chances of distress by nearly 5 percentage points. Interestingly, this outcome is not directly affected by having a teen mother (Table 4).

In sum, teen childbearing is likely to carry a number of disadvantages for mothers and their children. Whether or not these are a result of a selection based on unobserved background characteristics is not important here because our sibling-difference estimates have eliminated or limited their influence. The results in Table 5 suggest that an important channel through which the adverse effects of having a teen mother are transmitted to children's later outcomes is childhood family structure. Growing up in a non-intact family not only has detrimental consequences on its own (Ermisch and Francesconi, 2001b), but also magnifies the negative 
impact of having a teen mother on several young adults' behaviours. Conversely, the interaction between childhood family poverty and teenage childbearing does not seem to have a strong additional influence on child outcomes. This may be because family structure has indeed a stronger influence and 'wipes out' the impact of poverty. But it may also be because our proxy measure for family poverty (parental worklessness) is not adequate. Further analysis will clearly add on our understanding of both channels, and is left for future research.

\subsection{Discontinuities in the Effect of Mother's Age at Birth}

Our final exercise is to check whether there are systematic discontinuities in the effect of mother's age at birth. With this exercise we try to see if being born to a teen mother is worse (in terms of the outcomes under analysis) than being born to a slightly older mother or to a mother in her thirties. This is important because public resources devoted to young parents are generally directed to teenage mothers and their children rather than the broader group of socioeconomically disadvantaged families, which may comprise households with older parents.

We only present results from level and fixed-effects regressions. The between-family estimates were obtained from one regression for each outcome that included four age-group dummy variables: less than 20, 20-23, 28-31, and more than 31, with the group 24-27 serving as the base category. ${ }^{26}$ The within-family estimates instead were obtained from five separate logit regressions with different independent variables based on mother's age at birth: less than 20 (as in Table 4), less than 24, less than 28, more than 31, and more than 35. Table 6 reports the results.

The level estimates in panel A reveal that some outcomes are unaffected by the mothers' age at birth. Children of teen mothers and children of older mothers (in any of the other four age groups) tend to be similar in terms of their smoking, psychological distress, and hourly wages.

\footnotetext{
${ }^{26}$ We have experimented with other partitions of the post-teenage period and found similar patterns to those reported here. For simplicity such correlations are not shown. Differently from Levine et al. (2001), our sample is too small to distinguish further age groups within the teen years. We cannot therefore assess whether childbearing in the early teen years affects children differently than in the later teen years.
} 
(Indeed among such outcomes, no significant effects were found in Table 4). But for the other outcomes the picture is different. In the case of education and inactivity, for instance, we find adverse effects for children of both teen mothers and mothers aged 20-23 at birth, and beneficial effects for children born to mothers aged 31 or more at birth. For teenage childbearing, earnings and income, the harmful impact of having a younger mother (aged 23 or less) is still present, but there is no positive effect of having an older mother. ${ }^{27}$

Panel B of Table 6 contains the results from the within-family regressions. The first column reports the same estimates as those shown in the last column of Table 4 . We present them here once more for ease of exposition. The estimates in the panel confirm our previous results: increasing the age-at-birth cutoff to 24 does not reduce the adverse effects for children of young mothers. For example, being born to a mother aged less than 24 reduces the probability of achieving A-level of higher qualifications by about 7 percentage point, increases the risks of inactivity and teenage childbearing by 4 and 2 percentage points, and increases the probability of being the bottom decile of the earnings distribution by more than 3 percentage points. There are also some advantages from being born to older mothers (e.g., lower risks of unemployment and teenage fertility, and higher probability of being in the top decile of the income distribution), but most of the effects of mother's age at birth tend to disappear among children born to women aged 28 or more.

Therefore, children of teen mothers usually achieve inferior outcomes, but so do children of other young mothers who gave birth before their $24^{\text {th }}$ birthday, perhaps only to a lesser extent. Children of older mothers are presumably not affected by when exactly their mothers gave birth, or they may even be positively affected as in the case of education and employment. Public policies targeting teenage mothers and their children may be an effective strategy for alleviating

\footnotetext{
${ }^{27}$ It is worthwhile noticing that children of teen mothers have a lower probability of being in the bottom decile of the income distribution as compared to those born to mothers aged 24-27. This effect must be combined with the opposite (and larger) effect on monthly earnings, and it may reflect government transfers towards young people in poverty.
} 
the unfavourable conditions in which they generally live. But they may not be enough to tackle child poverty and disadvantage for children of (slightly) older mothers who too must face rather disadvantageous life opportunities.

\section{Conclusions}

This paper has estimated the relationship between several child outcomes measured in early adulthood and whether or not young adults were born to teenage mothers. Using data from the British Household Panel Survey, we have presented evidence from standard cross-sectional multivariate regression estimates, as well as from estimates that account for unmeasured family background heterogeneity by comparing siblings (or half-siblings) born to the same mother who timed their births at different ages. We also computed nonparametric estimates and Manski bounds around the effect of having a teenage mother.

We draw attention to three aspects of our results. First, regardless of the estimation technique, being born to a teen mother is typically associated with worse outcomes as young adults. Compared to children born to nonteen mothers, children of teen mothers have a lower chance of high educational attainment, greater risks of inactivity and teenage childbearing, a smaller probability of being in the top decile of the income distribution and a greater probability of being in the bottom decile of the earnings distribution. Second, a key channel of transmission of these adverse effects is childhood family structure, which in this case plays a more important role than family poverty during childhood. So growing up in a non-intact family tends to exacerbate the negative impact of having a teen mother on young adults' outcomes. Third, a few adverse consequences of early childbearing are faced not only by children of teen mothers but also by children of other older mothers (who gave birth before their $24^{\text {th }}$ birthday).

Recent analyses have raised questions about the causal linkages between the timing of fertility and young mothers' later outcomes. Many have argued that research on teen childbearing has overstated its negative consequences for mothers by ignoring the fact that 
teenage parents are drawn disproportionately from the ranks of the socially and economically disadvantaged. The findings of this paper, however, point to the general conclusion that children born to young mothers (aged 23 or less) are, on average, less successful than children of older mothers over a wide range of aspects of life. This holds true even after controlling for common unobserved family or maternal background factors. So early motherhood is not just a symptom, but it may be a cause of socioeconomic disadvantages that are transmitted across generations. Reduction of early (and not just teen) childbearing will not eradicate child poverty, nor will it tackle the many powerful effects of growing up with poor parents. But it does represent a viable strategy for widening the life chances of already disadvantaged children. 


\section{References}

An, C-B., Haveman, R. and Wolfe, B. (1993) Teen out-of-wedlock births and welfare receipt: the role of childhood events and economic circumstances. Review of Economics and Statistics, 75, 195-208.

Ashenfelter, O. and Krueger, A. (1994) Estimates of the economic return to schooling from a new sample of twins. American Economic Review, 84, 1157-73.

Ashenfelter, O. and Rouse, C. (1998) Income, schooling and ability: evidence from a new sample of identical twins. Quarterly Journal of Eonomics, 113, 253-84.

Black, S.E., Devereux, P.J. and Salvanes, K.G. (2005) Why the apple doesn't fall far: understanding intergenerational transmission of human capital. American Economic Review, 95, 437-49.

Brien, M.J., Loya, G.E. and Pepper, J.V. (2002) Teenage childbearing and cognitive development. Journal of Population Economics, 15, 391-416.

Bronars, S.G. and Grogger, J. (1994) The economic consequences of unwed motherhood: using twin births as a natural experiment. American Economic Review, 84, 1141-56.

Card, J.J. (1981) Long-term consequences for children of teen parents. Demography, 18, 13756.

Chamberlain, G. and Griliches, Z. (1997) More on brothers. In P. Taubman (ed.), Papers in Kinometrics: Determinants of Socioeconomic Success Within and Between Families. Amsterdam: North Holland.

Chevalier, A. and Viitanen, T.K. (2003) The long-run labour market consequences of teenage motherhood in Britain. Journal of Population Economics, 16, 323-43.

Coley, R.L. and Chase-Lansdale P.L. (1998) Adolescent pregnancy and parenthood: recent evidence and future directions. American Psychologist, 53, 152-66.

Currie, J. and Cole, N. (1993) Welfare and child health: the link between AFDC participation and birth weight. American Economic Review, 83, 971-85.

Ermisch, J. and Francesconi, M. (2001a) The Effects of Parents' Employment on Children's Lives. London: Family Policy Study Centre for the Joseph Rowntree Foundation.

Ermisch, J. and Francesconi, M. (2001b) Family structure and children's achievements. Journal of Population Economics, 14, 249-70.

Ermisch, J., Francesconi, M. and Pevalin, D.J. (2001) Outcomes for Children of Poverty. Department for Work and Pensions Research Report No. 158. Leeds: The Stationery Office.

Ermisch, J., Francesconi, M. and Pevalin, D.J. (2004) Parental partnership and joblessness in childhood and their influence on young people's outcomes. Journal of the Royal Statistical Society, Series A, 167, 69-101.

Ermisch, J. and Pevalin, D.J. (2003) Does a 'teen birth' have longer-term impacts on the mother? Evidence from the 1970 British Cohort Study. ISER Working Paper No. 2003-28, University of Essex, October.

Furstenberg, F.F., Brooks-Gunn, J. and Morgan, S.P. (1987) Adolescent mothers and their children in later life. Family Planning Perspectives, 19, 142-51.

Geronimus, A.T. and Korenman, S. (1992) The socioeconomic consequences of teen childbearing reconsidered. Quarterly Journal of Economics, 107, 1187-1214.

Geronimus, A.T. and Korenman, S. (1993) Maternal youth or family background? On the health disadvantages of infants with teenage mothers. American Journal of Epidemiology, 137, 213-25.

Geronimus, A.T., Korenman, S. and Hillemeier, M.M. (1994) Does young maternal age adversely affect child development? Evidence from cousin comparisons in the United States. Population and Development Review, 20, 585-608.

Goldberg, D.P., Oldehinkel, T. and Ormel, J. (1998) Why GHO threshold varies from one place to another. Psychological Medicine, 28, 915-21. 
Goodman, A., Kaplan, G. and Walker, I. (2004) Understanding the effect of early motherhood in Britain: the effects on mothers. IFS Working Paper 04/18, London, September.

Graham, J., Beller, A.H. and Hernandez, P. (1994) The effect of child support on educational attainment. In I. Garfinkel, S. McLanahan and P. Robins (eds.) Child Support and Child Well-being. Washington, DC: Urban Institute Press, pp. 317-54.

Grogger, J. (1997) Incarceration-related costs of early childbearing. In R. Maynard (ed.) Kids Having Kids: Economic Costs and Social Consequences of Teen Pregnancy. Washington, DC: Urban Institute Press.

Hardy, J.B., Shapiro, S., Astone, N.M., Miller, T.L. and Brooks-Gunn, J. (1997) Adolescent childbearing revisited: the age of inner-city mothers at delivery is a determinant of their children's self-sufficiency at age 27 to 33. Pediatrics, 100, 802-09.

Haveman, R. and Wolfe, B. (1995) The determinants of children's attainments: a review of methods and findings. Journal of Economic Literature, 33, 1829-78.

Haveman, R., Wolfe, B. and Peterson, E. (1997) Outcomes for teens and young adults of adolescent parents. In R. Maynard (ed.) Kids Having Kids: Economic Costs and Social Consequences of Teen Pregnancy. Washington, D.C.: Urban Institute Press.

Hofferth, S. (1987) The social and economic consequences of teenage childbearing. In C. Hayes and S. Hofferth (eds.) Risking the Future: Adolescent Sexuality, Pregnancy, and Childbearing, volume 2. Washington, D.C.: National Academy Press.

Hoffman, S.D., Foster, E. M. and Furstenberg, F.F. Jr. (1993) Reevaluating the costs of teenage childbearing. Demography, 30, 1-13.

Holmlund, H. (2005) Estimating long-term consequences of teenage childbearing: an examination of the siblings approach. Journal of Human Resources, 40, 716-43.

Hotz, J.V., McElroy, S.W. and Sanders, S.G. (2002) Teenage childbearing and its life cycle consequences: exploiting a natural experiment. Unpublished paper. University of California Los Angeles, June. Available at 〈http://www.econ.ucla.edu/hotz/ working_papers/teen.pdf $\rangle$.

Hotz, J.V., Mullin, S. and Sanders, S.G. (1997) Bounding causal effects using data from a contaminated natural experiment: analysing the effects of teenage childbearing. Review of Economic Studies, 64, 575-603.

Iacovou, M. and Berthoud, R. (2000) Parents and Employment: An Analysis of Low-Income Families in the British Household Panel Survey. Department of Social Security Report No. 107. Leeds: Corporate Document Services.

Jenks, C. (1989) What is the underclass - and is it growing? Focus, 12, 14-26.

Joshi, H., Macran S. and Dex, S. (1996) Employment after childbearing and women's subsequent labour force participation: evidence from the British 1958 birth cohort. Journal of Population Economics, 9, 325-48.

Kahn, J.R. and Anderson, K.E. (1992) Intergenerational patterns of teenage fertility. Demography, 29, 39-57.

Kiernan K.E. (1997) Becoming a young parent: a longitudinal study of associated factors. British Journal of Sociology, 48, 406-28.

Kiernan, K.E. and Diamond, I. (1983) The age at which childbearing starts - a longitudinal study. Population Studies, 37, 363-80.

Klepinger, D., Lundberg, S. and Plotnick, R. (1999) How does adolescent fertility affect the human capital and wages of young women? Journal of Human Resources, 34, 421-48.

Levine, J., Pollack, H.A. and Comfort, M. (2001) Academic and behavioral outcomes among the children of young mothers. Journal of Marriage and the Family, 63, 355-69.

Manlove, J. (1997) Early motherhood in an intergenerational perspective: the experiences of a British cohort. Journal of Marriage and the Family, 59, 263-79.

Manski, C.F. (1989) Anatomy of the selection problem. Journal of Human Resources, 24, 34360 . 
Manski, C.F. (1990) Nonparametric bounds on treatment effects. American Economic Review Papers and Proceedings, 80, 319-23.

Manski, C.F. (1995) Identification Problems in the Social Sciences. Cambridge, Mass.: Harvard University Press.

Manski, C.F., Sandefur, G.D., McLanahan, S. and Powers, D. (1992) Alternative estimates of the effect of family structure during adolescence on high school graduation. Journal of the American Statistical Association, 87, 25-37.

Presser, H.B. (1978) Social factors affecting the timing of the first child. In W.B. Miller and L.F. Newman (eds.) The First Child and Family Formation. Carolina Population Center.

Ribar, D.C. (1994) Teenage fertility and high school completion. Review of Economics and Statistics, 76, 413-24.

Rosenzweig, M.R. (1986) Birth spacing and sibling inequality: asymmetric information within the family. International Economic Review, 27, 55-76.

Rosenzweig, M.R. and Wolpin, K.I. (1980) Testing the quantity-quality fertility model: the use of twins as a natural experiment. Econometrica, 48, 227-40.

Rosenzweig, M.R. and Wolpin, K.I. (1995) Sisters, siblings, and mothers: the effect of teen-age childbearing on birth outcomes in a dynamic family context. Econometrica, 63, 303-26.

Strauss, J. (1990) Household, communities and preschool children's nutrition outcomes: evidence from rural Cote d'Ivoire. Economic Development and Cultural Change, 38, 23161.

UNICEF. (2001) A League Table of Teenage Births in Rich Nations. Florence: Innocenti Research Centre, July. 
Table 1a: The sample of young adults by gender

\begin{tabular}{lccc}
\hline & Men & Women & Total \\
\hline Number of individuals & & & \\
Number of person-wave observations & 948 & 839 & 1,787 \\
& 5,024 & 4,489 & 9,513
\end{tabular}

Source: British Household Panel Survey, 1991-1999.

Table $1 b$ : Distribution of siblings (individuals) and sibling pairs

\begin{tabular}{ccccc}
\hline & \multicolumn{4}{c}{ Number of: } \\
\cline { 2 - 5 } Sibling sample & $\begin{array}{c}\text { Siblings per } \\
\text { household }\end{array}$ & Households & Individuals & $\begin{array}{c}\text { Comparisons } \\
\text { (sibling pairs) }\end{array}$ \\
\hline & 2 & 408 & 816 & 408 \\
& 3 & 98 & 294 & 294 \\
& 4 & 17 & 68 & 102 \\
Total & 5 & 1 & 5 & 10 \\
& & 524 & 1,183 & 814
\end{tabular}

Note: Figures are from the subsample of individuals (reported in Table 1a) who can be matched to al least one sibling in any of the panel years.

Table 2: Child outcomes

\begin{tabular}{lrc}
\hline & $\%$ & $N$ \\
\hline Education & 62.3 & 1,489 \\
Economic inactivity & 7.2 & 9,513 \\
Teenage birth (women only) & 2.0 & 1,863 \\
Smoking & 42.5 & 9,513 \\
Psychological distress & 19.2 & 9,513 \\
Total income: & & \\
Bottom decile & 8.3 & 8,289 \\
Top decile & 6.5 & 8,289 \\
Hourly wages: & & \\
Bottom decile & 9.9 & 5,998 \\
Top decile & 9.8 & 5,998 \\
Monthly earnings: & & 6,071 \\
Bottom decile & 9.8 & 6,071 \\
Top decile & 9.9 &
\end{tabular}

Note: $N$ is the number of observations (individuals or person waves) that are relevant for the analysis of each outcome. 
Table 3: Summary statistics of mother's age at birth

\begin{tabular}{|c|c|c|c|c|c|c|}
\hline \multirow[b]{2}{*}{ Age of mother at birth } & \multirow[b]{2}{*}{ Mean } & \multicolumn{5}{|c|}{ Percentile } \\
\hline & & $5^{\text {th }}$ & $25^{\text {th }}$ & $\begin{array}{c}50^{\text {th }} \\
\text { (median) }\end{array}$ & $75^{\text {th }}$ & $90^{\text {th }}$ \\
\hline Age (years) & 26.5 & 19.3 & 23.2 & 26.2 & 29.6 & 32.8 \\
\hline \multicolumn{7}{|l|}{$\begin{array}{l}\text { Proportion of young } \\
\text { adults by mother-age- } \\
\text { at-birth group (\%): }\end{array}$} \\
\hline Less than 20 & 7.2 & & & & & \\
\hline $20-23$ & 24.6 & & & & & \\
\hline $24-27$ & 33.2 & & & & & \\
\hline $28-31$ & 22.0 & & & & & \\
\hline More than 31 & 13.0 & & & & & \\
\hline
\end{tabular}

Note: Figures are computed on the sample of all individuals $(\mathrm{N}=1,787)$ 
Table 4: The effect of being born to a teenage mother on adult child outcomes

\begin{tabular}{|c|c|c|c|c|c|c|}
\hline \multirow[b]{2}{*}{ Outcome } & \multirow{2}{*}{$\begin{array}{c}\text { Baseline } \\
\text { probability }\end{array}$} & \multicolumn{2}{|c|}{ Manski bounds } & \multirow{2}{*}{$\begin{array}{c}\text { Nonparametric } \\
\text { estimates }\end{array}$} & \multirow{2}{*}{$\begin{array}{c}\text { Level } \\
\text { estimates }\end{array}$} & \multirow{2}{*}{$\begin{array}{c}\text { Sibling } \\
\text { difference } \\
\text { estimates }\end{array}$} \\
\hline & & Lower & Upper & & & \\
\hline Education & 0.623 & $\begin{array}{l}-0.200^{*} \\
(0.091)\end{array}$ & $\begin{array}{c}0.050 \\
(0.048)\end{array}$ & $\begin{array}{l}-0.204 * \\
(0.050)\end{array}$ & $\begin{array}{l}-0.083^{*} \\
(0.039)\end{array}$ & $\begin{array}{l}-0.127^{*} \\
(0.062)\end{array}$ \\
\hline Economic inactivity & 0.072 & $\begin{array}{l}-0.047^{*} \\
(0.013)\end{array}$ & $\begin{array}{c}0.178^{*} \\
(0.026)\end{array}$ & $\begin{array}{c}0.063^{*} \\
(0.014)\end{array}$ & $\begin{array}{c}0.022 \\
(0.015)\end{array}$ & $\begin{array}{c}0.052 * \\
(0.009)\end{array}$ \\
\hline $\begin{array}{l}\text { Teenage birth } \\
\text { (women only) }\end{array}$ & 0.020 & $\begin{array}{l}-0.020^{*} \\
(0.008)\end{array}$ & $\begin{array}{l}0.368^{*} \\
(0.035)\end{array}$ & $\begin{array}{c}0.051^{*} \\
(0.019)\end{array}$ & $\begin{array}{c}0.025^{*} \\
(0.010)\end{array}$ & $\begin{array}{c}0.027^{*} \\
(0.010)\end{array}$ \\
\hline Smoking ${ }^{\mathrm{a}}$ & 0.425 & $\begin{array}{l}-0.178^{*} \\
(0.053)\end{array}$ & $\begin{array}{c}0.397 * \\
(0.055)\end{array}$ & $\begin{array}{l}0.057^{*} \\
(0.019)\end{array}$ & $\begin{array}{c}0.025 \\
(0.056)\end{array}$ & $\begin{array}{c}0.021 \\
(0.049)\end{array}$ \\
\hline $\begin{array}{l}\text { Psychological } \\
\text { distress }\end{array}$ & 0.192 & $\begin{array}{l}-0.089 * \\
(0.019)\end{array}$ & $\begin{array}{c}0.625^{*} \\
(0.063)\end{array}$ & $\begin{array}{c}0.028 \\
(0.017)\end{array}$ & $\begin{array}{c}0.027 \\
(0.022)\end{array}$ & $\begin{array}{c}0.032 \\
(0.065)\end{array}$ \\
\hline \multicolumn{7}{|l|}{ Total income: } \\
\hline Bottom decile & 0.083 & $\begin{array}{l}-0.005 \\
(0.005)\end{array}$ & $\begin{array}{c}0.401^{*} \\
(0.092)\end{array}$ & $\begin{array}{l}-0.004 \\
(0.017)\end{array}$ & $\begin{array}{c}0.002 \\
(0.018)\end{array}$ & $\begin{array}{c}0.012 \\
(0.113)\end{array}$ \\
\hline Top decile & 0.065 & $\begin{array}{l}-0.058^{*} \\
(0.027)\end{array}$ & $\begin{array}{l}0.164^{*} \\
(0.073)\end{array}$ & $\begin{array}{l}-0.040^{*} \\
(0.011)\end{array}$ & $\begin{array}{l}-0.035^{*} \\
(0.016)\end{array}$ & $\begin{array}{l}-0.027^{*} \\
(0.013)\end{array}$ \\
\hline \multicolumn{7}{|l|}{ Hourly wages: } \\
\hline Bottom decile & 0.131 & $\begin{array}{l}-0.016 \\
(0.009)\end{array}$ & $\begin{array}{c}0.281^{*} \\
(0.086)\end{array}$ & $\begin{array}{c}0.018 \\
(0.019)\end{array}$ & $\begin{array}{c}0.005 \\
(0.021)\end{array}$ & $\begin{array}{c}0.017 \\
(0.028)\end{array}$ \\
\hline Top decile & 0.070 & $\begin{array}{l}-0.061^{*} \\
(0.027)\end{array}$ & $\begin{array}{l}0.083^{*} \\
(0.025)\end{array}$ & $\begin{array}{l}-0.033^{*} \\
(0.012)\end{array}$ & $\begin{array}{l}-0.032 \\
(0.021)\end{array}$ & $\begin{array}{l}-0.041 \\
(0.107)\end{array}$ \\
\hline \multicolumn{7}{|l|}{ Monthly earnings: } \\
\hline Bottom decile & 0.129 & $\begin{array}{l}-0.005 \\
(0.009)\end{array}$ & $\begin{array}{c}0.621^{*} \\
(0.081)\end{array}$ & $\begin{array}{l}-0.031^{*} \\
(0.012)\end{array}$ & $\begin{array}{l}-0.023 \\
(0.017)\end{array}$ & $\begin{array}{c}0.034^{*} \\
(0.015)\end{array}$ \\
\hline Top decile & 0.073 & $\begin{array}{l}-0.011 \\
(0.009)\end{array}$ & $\begin{array}{c}0.121 \\
(0.088)\end{array}$ & $\begin{array}{l}-0.021^{*} \\
(0.010)\end{array}$ & $\begin{array}{l}-0.011 \\
(0.020)\end{array}$ & $\begin{array}{l}-0.021 \\
(0.084)\end{array}$ \\
\hline
\end{tabular}

Note: 'Manski bounds' and 'Nonparametric estimates' are estimated for 288 cells based on: individual's age (3 groups: age $\leq 19$; $20 \leq$ age $\leq 22$; and age $\geq 23$ ); individual is firstborn (2 groups); sex (2 groups); mother's education (2 groups: mother has less than A level qualification; mother has A level or higher qualification); father's education (father has less than A level qualification; father has A level or higher qualification); childhood family structure (2 groups: intact and non-intact family); and mother's age at birth (3 groups: age $<20$; 20 $\leq$ age $\leq 33$; and age $>33$ ). Manski bounds reported here are the largest of the lower bounds ('Lower') and the smallest of the upper bounds ('Upper') for the 288 cells. The 'Nonparametric estimates' report the weighted average of the 288 cell estimates, where the weights are given by the size of each cell in the sample. The 'Level estimates and the 'Sibling difference estimates' are marginal effects from logit regressions computed at average values of all variables used. Level regressions include: age (7 groups), sex, year of birth, mother's and father's education (5 groups each), father's and mother's age at birth (3 groups each), number of brothers and sisters, whether respondent experienced life in a non-intact family by age 16, whether respondent is the only child, whether respondent is firstborn, and a constant. Sibling difference models include sibling differences in: sex, age (years), age of father and mother at birth, childhood family structure and parental joblessness, whether firstborn or not, and a constant. Sister differences are taken at the same age in the case of the teenage birth outcome; in all other cases, age enters parametrically. Standard errors are in parentheses. Bootstrap standard errors for Manski bounds and nonparametric estimates are obtained with 500 bootstrap replications. Standard errors for the level and sibling difference estimates are robust to arbitrary forms of heteroskedasticity. Standard errors for the sibling difference estimates are also robust to within-family clustering.

${ }^{a}$ Controls for mother's and father's smoking (level regression only)

* significant at the 0.05 level. 
Table 5: Channels of transmission: childhood family structure and poverty - Sibling difference estimates

\begin{tabular}{|c|c|c|c|}
\hline \multirow[b]{2}{*}{ Outcome } & \multicolumn{3}{|c|}{ Treatment variable and interaction terms } \\
\hline & $\begin{array}{l}\text { Mother was } \\
\text { aged } \\
\text { less than } 20 \\
\text { at child's birth } \\
\text { ('Teen mother') }\end{array}$ & $\begin{array}{l}\text { 'Teen mother' × } \\
\text { Ever lived in a } \\
\text { non-intact } \\
\text { family during } \\
\text { childhood }\end{array}$ & $\begin{array}{c}\text { 'Teen mother' } \times \\
\text { Ever lived with } \\
\text { workless parents } \\
\text { during } \\
\text { childhood }\end{array}$ \\
\hline Education & $\begin{array}{l}-0.055 \\
(0.036)\end{array}$ & $\begin{array}{l}-0.072 * \\
(0.035)\end{array}$ & $\begin{array}{l}-0.027 \\
(0.034)\end{array}$ \\
\hline Economic inactivity & $\begin{array}{c}0.037^{*} \\
(0.012)\end{array}$ & $\begin{array}{c}0.028^{*} \\
(0.013)\end{array}$ & $\begin{array}{c}0.020 \\
(0.032)\end{array}$ \\
\hline Teenage birth (women only) & $\begin{array}{c}0.020^{*} \\
(0.006)\end{array}$ & $\begin{array}{c}0.009 * \\
(0.004)\end{array}$ & $\begin{array}{l}-0.002 \\
(0.024)\end{array}$ \\
\hline Smoking & $\begin{array}{c}0.001 \\
(0.033)\end{array}$ & $\begin{array}{c}0.052 * \\
(0.018)\end{array}$ & $\begin{array}{c}0.013 \\
(0.021)\end{array}$ \\
\hline Psychological distress & $\begin{array}{c}0.019 \\
(0.073)\end{array}$ & $\begin{array}{c}0.023 \\
(0.059)\end{array}$ & $\begin{array}{c}0.047^{*} \\
(0.023)\end{array}$ \\
\hline \multicolumn{4}{|l|}{ Total income: } \\
\hline $\begin{array}{l}\text { Bottom decile } \\
\text { Top decile }\end{array}$ & $\begin{array}{c}0.017 \\
(0.124) \\
-0.026^{*} \\
(0.013)\end{array}$ & $\begin{array}{c}0.011 \\
(0.082) \\
-0.026^{*} \\
(0.012)\end{array}$ & $\begin{array}{l}-0.005 \\
(0.113) \\
-0.020 \\
(0.036)\end{array}$ \\
\hline \multicolumn{4}{|l|}{ Hourly wages: } \\
\hline Bottom decile & $\begin{array}{c}0.015 \\
(0.028)\end{array}$ & $\begin{array}{c}0.021 \\
(0.018)\end{array}$ & $\begin{array}{c}0.019 \\
(0.021)\end{array}$ \\
\hline Top decile & $\begin{array}{l}-0.029 \\
(0.089)\end{array}$ & $\begin{array}{l}-0.016 \\
(0.071)\end{array}$ & $\begin{array}{l}-0.023 \\
(0.065)\end{array}$ \\
\hline \multicolumn{4}{|l|}{ Monthly earnings: } \\
\hline Bottom decile & $\begin{array}{c}0.030 * \\
(0.014)\end{array}$ & $\begin{array}{c}0.031 * \\
(0.015)\end{array}$ & $\begin{array}{c}0.007 \\
(0.051)\end{array}$ \\
\hline Top decile & $\begin{array}{l}-0.009 \\
(0.126)\end{array}$ & $\begin{array}{l}-0.032 * \\
(0.015)\end{array}$ & $\begin{array}{l}-0.021 \\
(0.074)\end{array}$ \\
\hline
\end{tabular}

Note: The figures are marginal effects from sibling-difference (logit) regressions, computed at average values of all variables used in estimation. For a list of such variables, see the note to Table 4.

* significant at the 0.05 level. 
Table 6: Discontinuities in the effect of mother's age at birth on child outcomes

\begin{tabular}{|c|c|c|c|c|c|}
\hline \multirow[b]{2}{*}{ A. Level estimates } & \multicolumn{5}{|c|}{ Mother's age at birth (years) } \\
\hline & $\begin{array}{c}\text { Less } \\
\text { than } 20\end{array}$ & $20-23$ & $24-27$ & 28-31 & $\begin{array}{c}\text { More } \\
\text { than } 31 \\
\end{array}$ \\
\hline Education & $\begin{array}{l}-0.101^{*} \\
(0.051)\end{array}$ & $\begin{array}{l}-0.064 * \\
(0.031)\end{array}$ & (ref.) & $\begin{array}{c}0.059 \\
(0.033)\end{array}$ & $\begin{array}{c}0.190^{*} \\
(0.057)\end{array}$ \\
\hline Economic inactivity & $\begin{array}{c}0.025^{*} \\
(0.010)\end{array}$ & $\begin{array}{r}0.010 \\
(0.010\end{array}$ & (ref.) & $\begin{array}{l}-0.007 \\
(0.011)\end{array}$ & $\begin{array}{l}-0.026^{*} \\
(0.012)\end{array}$ \\
\hline $\begin{array}{l}\text { Teenage birth } \\
\text { (women only) }\end{array}$ & $\begin{array}{c}0.038^{*} \\
(0.012)\end{array}$ & $\begin{array}{c}0.022 * \\
(0.008)\end{array}$ & (ref.) & $\begin{array}{c}0.001 \\
(0.013)\end{array}$ & $\begin{array}{l}-0.049 \\
(0.027)\end{array}$ \\
\hline Smoking & $\begin{array}{c}0.038 \\
(0.052)\end{array}$ & $\begin{array}{c}0.043 \\
(0.035)\end{array}$ & (ref.) & $\begin{array}{l}-0.054 \\
(0.036)\end{array}$ & $\begin{array}{l}-0.032 \\
(0.058)\end{array}$ \\
\hline Psychological distress & $\begin{array}{c}0.033 \\
(0.024)\end{array}$ & $\begin{array}{c}0.008 \\
(0.016)\end{array}$ & (ref.) & $\begin{array}{c}0.011 \\
(0.016)\end{array}$ & $\begin{array}{c}0.021 \\
(0.024)\end{array}$ \\
\hline \multicolumn{6}{|l|}{ Total income: } \\
\hline Top decile & $\begin{array}{l}(0.016) \\
-0.015 \\
(0.023)\end{array}$ & $\begin{array}{c}(0.010) \\
0.006 \\
(0.013)\end{array}$ & (ref.) & $\begin{array}{l}(0.009) \\
-0.012 \\
(0.009)\end{array}$ & $\begin{array}{c}(0.013) \\
0.019 \\
(0.022)\end{array}$ \\
\hline \multicolumn{6}{|l|}{ Hourly wages: } \\
\hline Bottom decile & $\begin{array}{c}0.011 \\
(0.023)\end{array}$ & $\begin{array}{c}0.016 \\
(0.015)\end{array}$ & (ref.) & $\begin{array}{l}-0.004 \\
(0.011)\end{array}$ & $\begin{array}{l}-0.000 \\
(0.608)\end{array}$ \\
\hline Top decile & $\begin{array}{l}-0.036 \\
(0.024)\end{array}$ & $\begin{array}{l}-0.017 \\
(0.011)\end{array}$ & (ref.) & $\begin{array}{l}-0.001 \\
(0.007)\end{array}$ & $\begin{array}{c}0.002 \\
(0.014)\end{array}$ \\
\hline \multicolumn{6}{|l|}{ Monthly earnings: } \\
\hline Bottom decile & $\begin{array}{c}0.057 * \\
(0.015)\end{array}$ & $\begin{array}{c}0.042 \\
(0.025)\end{array}$ & (ref.) & $\begin{array}{c}0.011 \\
(0.024)\end{array}$ & $\begin{array}{c}0.000 \\
(0.010)\end{array}$ \\
\hline Top decile & $\begin{array}{l}-0.038 * \\
(0.014)\end{array}$ & $\begin{array}{l}-0.016 \\
(0.010)\end{array}$ & (ref.) & $\begin{array}{l}-0.016 \\
(0.132)\end{array}$ & $\begin{array}{c}0.001 \\
(0.002)\end{array}$ \\
\hline $\begin{array}{l}\text { B. Sibling difference } \\
\text { estimates }\end{array}$ & $\begin{array}{l}\text { Less } \\
\text { than } 20\end{array}$ & $\begin{array}{c}\text { Less } \\
\text { than } 24\end{array}$ & $\begin{array}{c}\text { Less } \\
\text { than } 28\end{array}$ & $\begin{array}{l}\text { More } \\
\text { than } 31\end{array}$ & $\begin{array}{l}\text { More } \\
\text { than } 35\end{array}$ \\
\hline Education & $\begin{array}{l}-0.127^{*} \\
(0.062)\end{array}$ & $\begin{array}{l}-0.071^{*} \\
(0.034)\end{array}$ & $\begin{array}{l}-0.035 \\
(0.049)\end{array}$ & $\begin{array}{c}0.028 \\
(0.037)\end{array}$ & $\begin{array}{c}0.024 \\
(0.056)\end{array}$ \\
\hline Economic inactivity & $\begin{array}{c}0.052 * \\
(0.009)\end{array}$ & $\begin{array}{l}0.042^{*} \\
(0.010)\end{array}$ & $\begin{array}{c}0.021 \\
(0.016)\end{array}$ & $\begin{array}{l}-0.020^{*} \\
(0.008)\end{array}$ & $\begin{array}{c}0.002 \\
(0.014)\end{array}$ \\
\hline $\begin{array}{l}\text { Teenage birth } \\
\text { (women only) }\end{array}$ & $\begin{array}{c}0.027 * \\
(0.010)\end{array}$ & $\begin{array}{c}0.020 * \\
(0.009)\end{array}$ & $\begin{array}{c}0.003 \\
(0.011)\end{array}$ & $\begin{array}{l}-0.018 \\
(0.010)\end{array}$ & $\begin{array}{l}-0.025^{*} \\
(0.012)\end{array}$ \\
\hline Smoking & $\begin{array}{c}0.021 \\
(0.049)\end{array}$ & $\begin{array}{c}0.022 \\
(0.051)\end{array}$ & $\begin{array}{l}-0.001 \\
(0.027)\end{array}$ & $\begin{array}{l}-0.020 \\
(0.035)\end{array}$ & $\begin{array}{l}-0.029 \\
(0.026)\end{array}$ \\
\hline Psychological distress & $\begin{array}{c}0.032 \\
(0.065)\end{array}$ & $\begin{array}{c}0.037 \\
(0.059)\end{array}$ & $\begin{array}{c}0.017 \\
(0.045)\end{array}$ & $\begin{array}{l}-0.014 \\
(0.042)\end{array}$ & $\begin{array}{l}-0.015 \\
(0.050)\end{array}$ \\
\hline
\end{tabular}

Total income: 


$\begin{array}{llllll}\text { Bottom decile } & 0.011 & 0.021 & 0.009 & -0.035 & -0.031 \\ \text { Top decile } & (0.101) & (0.087) & (0.076) & (0.047) & (0.052) \\ & -0.028^{*} & -0.025^{*} & -0.010 & 0.019 & 0.024^{*} \\ & (0.013) & (0.012) & (0.014) & (0.015) & (0.012)\end{array}$

Hourly wages:

$\begin{array}{lllllc}\text { Bottom decile } & 0.017 & 0.018 & -0.012 & -0.024 & -0.024 \\ \text { Top decile } & (0.026) & (0.032) & (0.022) & (0.019) & (0.033) \\ & -0.038 & -0.042 & -0.004 & 0.022 & 0.020 \\ & (0.104) & (0.109) & (0.087) & (0.031) & (0.024)\end{array}$

Monthly earnings:

Bottom decile

$\begin{array}{llccc}0.034^{*} & 0.033^{*} & -0.004 & -0.027 * & -0.026 \\ (0.016) & (0.014) & (0.023) & (0.013) & (0.015) \\ -0.021 & -0.020 & 0.009 & 0.035 & 0.032 \\ (0.083) & (0.087) & (0.044) & (0.038) & (0.054)\end{array}$

Note: The figures are marginal effects computed at average values of all variables used in estimation. For a list of such variables, see the note to Table 4.

* significant at the 0.05 level. 
Table A1: Child outcomes within and between families

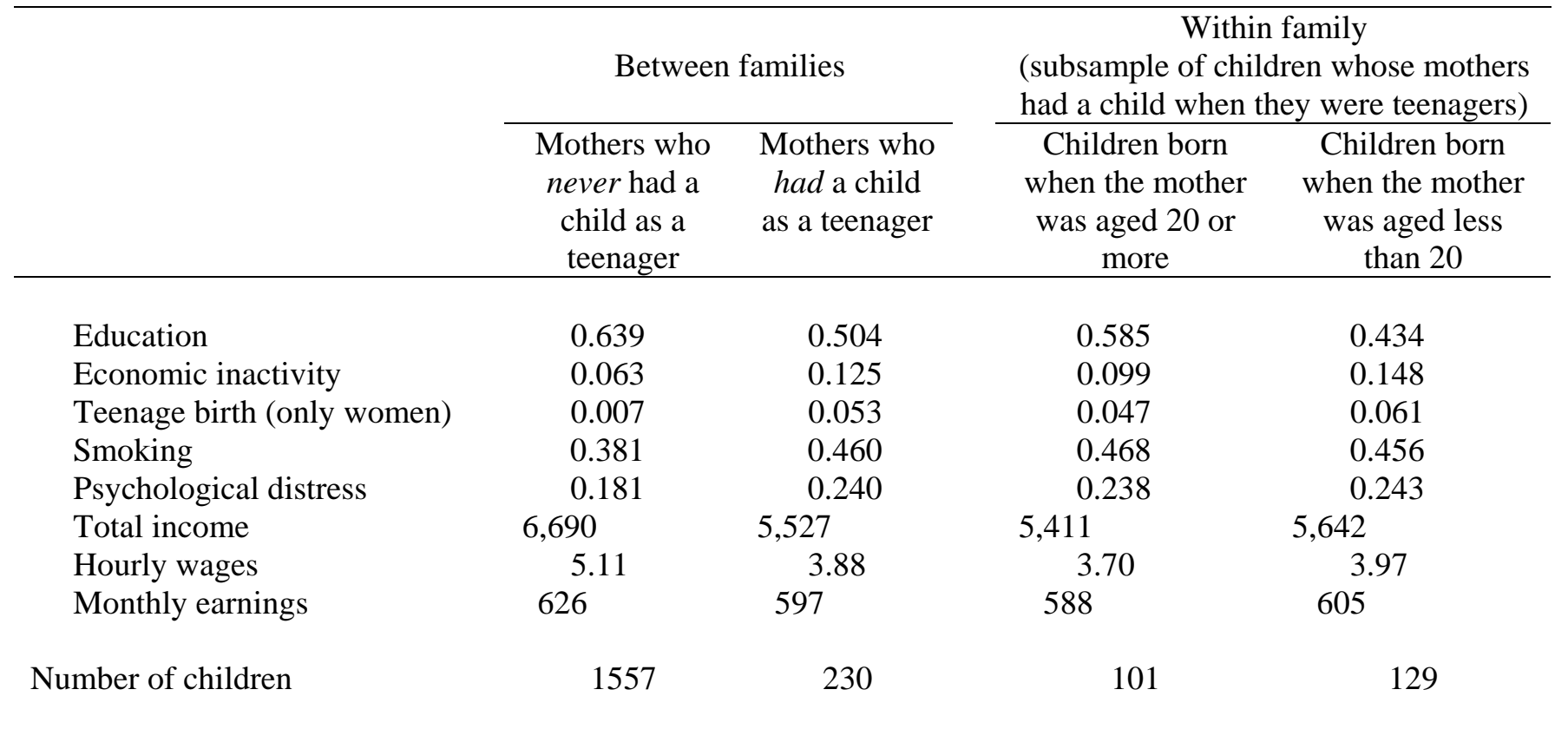

Note: Figures are means computed on the sample of individuals $(\mathrm{N}=1,787)$. For each individual, the means of outcomes that are time varying are computed over all the available waves of data. 
Table A2: Summary statistics of the other variables used in the analysis

\begin{tabular}{|c|c|c|}
\hline Variable & Mean & $\begin{array}{l}\text { Standard } \\
\text { deviation }\end{array}$ \\
\hline Female & 0.470 & \\
\hline Age (years) & 22.062 & 3.680 \\
\hline \multicolumn{3}{|l|}{ Age group: } \\
\hline 16 (base) & 0.078 & \\
\hline 17 & 0.089 & \\
\hline 18 & 0.083 & \\
\hline 19 & 0.091 & \\
\hline 20 & 0.091 & \\
\hline 21 & 0.089 & \\
\hline 22 & 0.082 & \\
\hline 23 and more & 0.397 & \\
\hline Year of birth - 1900 & 76.547 & 3.786 \\
\hline Age of father at birth (years) ${ }^{a}$ & 29.068 & 5.573 \\
\hline \multicolumn{3}{|l|}{ Age of father at birth: } \\
\hline Less than 20 & 0.033 & \\
\hline $20-25$ & 0.186 & \\
\hline 26-30 (base) & 0.400 & \\
\hline 31-35 & 0.257 & \\
\hline More than 35 & 0.124 & \\
\hline \multicolumn{3}{|l|}{ Mother's education: } \\
\hline No qualification (base) & 0.301 & \\
\hline Less than O-level (or equivalent) & 0.103 & \\
\hline O-level or equivalent & 0.202 & \\
\hline A-level of equivalent & 0.071 & \\
\hline Higher vocational qualifications & 0.245 & \\
\hline University and higher degrees & 0.078 & \\
\hline \multicolumn{3}{|l|}{ Father's education: ${ }^{\mathrm{a}, \mathrm{b}}$} \\
\hline No qualification (base) & 0.244 & \\
\hline Less than O-level (or equivalent) & 0.076 & \\
\hline O-level or equivalent & 0.165 & \\
\hline A-level of equivalent & 0.107 & \\
\hline Higher vocational qualifications & 0.298 & \\
\hline University and higher degrees & 0.109 & \\
\hline Ever lived in a non-intact family during childhood & 0.249 & \\
\hline \multicolumn{3}{|l|}{ Ever lived in a non-intact family when aged: } \\
\hline $0-5$ & 0.107 & \\
\hline $6-10$ & 0.078 & \\
\hline $11-15$ & 0.063 & \\
\hline Parent's joblessness during childhood ${ }^{\mathrm{C}}$ & 0.468 & \\
\hline \multicolumn{3}{|l|}{ Parent’s joblessness when aged: ${ }^{c}$} \\
\hline $0-5$ & 0.387 & \\
\hline $6-10$ & 0.252 & \\
\hline $11-15$ & 0.176 & \\
\hline Number of brothers & 0.908 & 0.874 \\
\hline Number of sisters & 0.805 & 0.875 \\
\hline Only child & 0.072 & \\
\hline Firstborn & 0.360 & \\
\hline Mother smokes & 0.224 & \\
\hline Father smokes ${ }^{\mathrm{a}, \mathrm{d}}$ & 0.565 & \\
\hline Missing father's information & 0.296 & \\
\hline Missing father’s work history & 0.167 & \\
\hline
\end{tabular}


${ }^{\mathrm{a}}$ Computed on the sample of young adults with non-missing father's information $(\mathrm{N}=1,258)$.

b In the multivariate analysis, cases with missing information are included in the 'no qualification' (base) category.

c In the multivariate analysis, cases with missing information have been assigned to the 'working' (base) category.

' In the multivariate analysis, cases with missing information are included in the 'non smoking' (base) category.

Table A3: Child characteristics within and between families

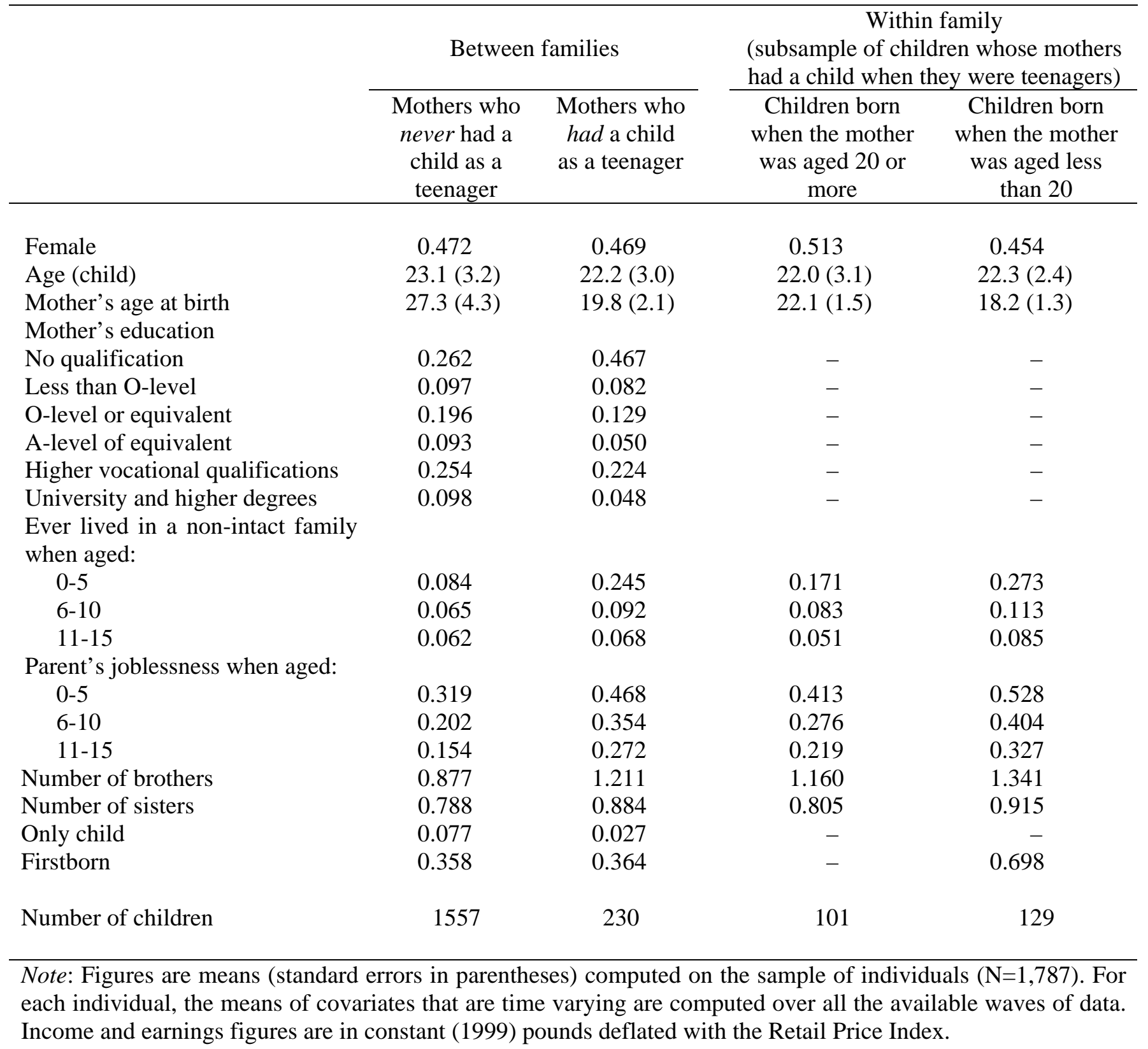

